\title{
Development of Corporate Culture Based on Improving the Motivation System of the Bank's Staff
}

\author{
DAlexandra Khon ${ }^{1}$ Bc. ed.; Zukhra Sadvakassova ${ }^{2}$ Candidate of pedagogical sciences \\ (D)Akmaral Magauova ${ }^{3}$ Doctor of pedagogical sciences; Malika Nazarova ${ }^{4}$ Bc. ed. \\ Al-Farabi Kazakh National University, Kazakhstan \\ hon.aleksandra@bk.ru¹; zuhra76@mail.ru²; magauova@mail.ru³; takenova.malika@mail.ru4
}

\begin{abstract}
The relevance of the topic lies in the fact that the transition to innovative personal management is currently a global trend to improve enterprise management processes in the context of deep integration of the world market, high-tech industries, increased competition and improved uncertainty of the external environment in relation to the enterprise, considering the motivational system. The purpose of the research is to study the role of motivation and corporate culture as the basis for innovative development and improving the productivity of an organization. The database was used by a banking organization; for instance, during the study the approaches of scientists were studied and diagnostic methods for studying the components of corporate culture were selected. Based on the results, a model of practical implementation was formulated, and a sociological experiment was conducted. On this ground using results of the experiment, statistical data on labour productivity were obtained and methodological recommendations were made for using the model proposed in the article. The results obtained are presented as a diagnostic tool and used to include the contact centre management in the work process.
\end{abstract}

Keywords: corporate culture, team building, motivation system in bank.

\section{Introduction}

The desire of the sovereign Republic of Kazakhstan to take a worthy place among developed countries with a stable economy puts forward as a priority the improvement of the quality of human capital as the basis for the state's competitiveness in the world community. In the structure of interrelations of elements reflecting the system - integral nature of this quality, team building and its corporate culture, considering the motivation system, is a system-forming factor that ensures the life of society, social groups, and a particular person. E.H. Schein agree that culture is the main source of an organization's identity and reflects the beliefs and values of the founder (Schein, 2013); culture has become a popular concept leading to a wide variety of research and implementation by various organizations, the role of leadership varies with the age of the organization from founding, through mid-life to old age as cultural issues vary at each stage (Schein, Schein, 2016). Historically, corporate employees were portrayed as communities with a common consciousness, they could be imagined as an extended family, and later the idea of a brand community emerged (Heller, Rowlinson, 2020). Questions about the development of corporate culture became the object of universal research, and did not only involve traditional historiographical analysis, but also included a study of archives, correspondence, resolutions and other regulatory banking documents, from which a general idea of the corporate component adopted in a given banking organisation was constructed (Mooij, 2004, 21). A.E. Dabija (2019) mentioned that organizational culture influences the performance of banking organizations. It was found out that many times it is difficult to improve the performance of the bank and to increase the level of motivation of the employees, because it aims to make a short-term profit, without the decision-makers concerned about the satisfaction of the employees.

As noted in the study (Ivanova, Ignatjeva, 2018, 364), the consistency of personal values and organizational values allows us to determine the level of support and acceptance of organizational values by employees, and helps to determine, thus, whether the direction of development is sufficiently supported by employees, and allows us to assess the readiness of the organization for change and the level of organizational culture in general.

As J. Hellevig emphasizes, within a dynamic corporative culture that actively interacts with the market, the most important thing is new creative ideas about how new creative technologies can be used in the company's business processes (Hellevig, 2012, 4). Research evidence argues that there is a strong focus on using culture as a potential for leading change and enhancing innovation in organisations (Carretta et 
al., 2006, 22). Management is considered by us as follows, based on the theory of team building, the implementation of innovation development management requires the creation of a special stimulating environment in the organization, in which the creative activity and initiative of people is realized (Dyer, Dyer, Dyer, 2007). O.A. Sergienko has developed a model for assessing the impact of employee motivation factors on the bank's performance, in which financial, social incentives and medical insurance are recommended as motivating components (Sergienko et al., 2018). By realizing their creative potential and getting satisfaction from their work, people form an innovative culture of the environment. Such an environmental culture, its innovative spirit, will provide employees of the organization with the self-confidence necessary to search for, offer original solutions, experiment, defend their position, and freely express their own opinions. A well-thought-out organizational management system that creates a flexible and adaptive management system contributes to the innovation of the environment. The environment formed under such conditions depends on the introduction of innovations, the attractiveness of motivational mechanisms, the ability to innovate, especially in the field of work or process, and affects the improvement of not only cohesion, corporate spirit, but also the competitiveness of the organization itself (Wheelwright, Clark, 1992, 9).Interestingly, the researchers also see corporate culture as a social norm, not just a management control strategy, and suggest that organisations should seek to manage in a culturally sensitive way rather than just managing culture. (O'Donnell, Boyle, 2008, 15). Adaptation of employee values can include both external and internal motivation. It has been shown that internal motives are formed under the influence of external motivation. To stimulate the work activities of employees, the staff of banking institutions use various methods of influencing the behaviour of employees, both tangible and intangible (Kuzmynchuk et al., 2020). In human resources management, each manager is faced with the fact that when choosing a staff that satisfies all criteria, they are dismissed. And it begs questions about how to save valuable human resources, whether the decision to dismiss depends on the level of motivation, and what to consider for the manager to work for pleasure.

Researchers' findings highlight the important role of national culture, and research has found that countries with greater workplace harmony will have lower loan interest rate differentials. It is important that the company has more research capacity and development intensity, this will ensure more productive work (Cheung, Tan, Wang, 2020). In practice, there are many tools that managers use in their working time, depending on the working conditions, individual characteristics of employees and, additionally, the management culture, which is directly related to updating knowledge and considering modern management trends. J. Davidova and I. Kokina (2018) acknowledge that the value of an organization can be increased if the use of information and knowledge is approached holistically. Organizational learning has become an increasingly important study area over the past decades (Argyris, Schön, 1995; Senge, 2006). The researchers found that companies that invest more effort in achieving higher-level organisational learning gain in both financial and nonfinancial terms (Arh, Jerman Blaézic, Dimovski, 2012, 379). Knowledge management is the art of transforming information and intellectual assets into a lasting value for the organization's value "Customers" and its people. According to A. Kibanov, the incentive system must be responsive and adaptable to changes of any order (Kibanov et al., 2015). Moreover, researchers have empirically proven that competition-oriented firms, by attracting competitive workers, benefit from strong internal competition among employees, which increases firm value (Barth, 2015, 28), as well as bank management should motivate employees through fair remuneration to reduce staff fear and anxiety (Padmavathi, Subrahmanyam, 2018, 527).

Employee intrinsic motivation refers to a category of psychological state of mind in which an employee possesses personality traits that enable them to perform effectively without administrative influence. People with higher levels of intrinsic motivation for certain behaviours are better able to perform the intended actions and maintain them over time (Ryan, Connell, 1989, 749). An example of intrinsic motivation is how an employee feels self-actualised as a result of doing a task well. The criteria for internal motivation of an employee are their interest in the company's mission and goals, in the company's success and results, and their desire to cope with difficulties and tasks, their intention to develop on the career ladder, and finally their satisfaction with the results of their work (Nasri, Charfeddine, 2012, 169). For large banking companies providing complex financial services, the issue of developing a unified corporate culture to guide the actions of all employees becomes a challenge (Thakor, 2016, 6). 
The level of employee engagement is determined by initiative, the desire to actively participate in the life of the organization, there is a high level of proactivity in performing corporate tasks, the basis of a good development perspective in the future the employee intends to stay in this area for a long time, is ready to perform additional tasks, the employee is responsible for each task, strives to improve work processes, make small action but significant changes, is friendly to colleagues and open to innovation.

The purpose of the research is to study the role of motivation and corporate culture as the basis for innovative development and improving the productivity of an organization.

\section{Methodology}

The authors put forward the following hypotheses:

1. if you develop the level of corporate culture based on the motivational system, the organization's productivity will increase;

2. the motivational system for employees is effective not only when using material (monetary) incentives;

3. for employees of the call centre, the main motivating incentive is material remuneration.

Further research was conducted to prove or disprove our hypotheses. The research was based on a banking organization, namely, 51 employees of the call centre in the period from July 2020 to November 2020.

To diagnose the current state of labour motivation of the staff, the following methods were used: the employee engagement questionnaire Q12 by assessment of involvement in work (Tokareva, Baronene, 2019, 15) and the method of Yu.M. Orlov (the questionnaire "Need to achieve a goal" (Golovey, Rybalko, 2002, 512-513)) tested on 51 employees of the call centre Department, who presented us with the following results.

\section{Results and discussion}

According to the results of the questionnaire to identify the level of "need to achieve the goal", only $20 \%$ of the call centre has increased "need to achieve the goal", $47 \%$ of employees have an average "need to achieve the goal", and $23 \%$ have a low need to achieve.

The level of involvement in the work of call centre employees is represented by the following results: $30 \%$ have a satisfactory level, but not sufficient, and $70 \%$ have a low level of involvement.

The current state of culture in the team has prompted us to create a model for influencing the level of employee engagement and internal motivation in general activities through teamwork.

A high level of future culture can be achieved by creating favourable conditions, introducing the principles of mutual support and assistance into the team, maintaining friendly relations with the leadership and having a common mission (Tikhomirova, 2014, 162-167). The authors of the article agree with this view.

As research by academics shows, banks are more focused on net profit in management, so employees set goals for earning bonuses and receiving bonuses and rewards. Understanding and accepting this fact will allow building an effective incentive system based on the bank's accepted norms (Bennett, Gopalan, Thakor, 2016, 22).

The teamwork model is based on the principle of a systematic approach, bearing in mind the specifics of the employee's tasks and the necessary competencies. The author's model reflects the objective of teamwork development, the principles and the algorithm for achieving results (Figure 1). The system of teamwork, which was built based on a reasonable distribution of work and rest time, an increase in moral support from the management and regular training of employees, was introduced and controlled by group curators.

Banking requires a qualified approach to work; continuous update of the content of the services provided, the introduction of new system processes, the replacement of banking procedures with various programs of independent use increases the need for employees to develop skills of rapid learning, multitasking skills, skills in clear analysis and developed logic in perceived information.

It should be noted that the comprehensive development of corporate culture, interconnected with the motivation of personnel to work, affects the results not only of each employee individually, but as a whole, affects the results of the entire banking organization. Based on the works of research scientists 
who presented us with methods for organizing working time, stimulating personnel in moral and material ways, the authors have selected and applied several options for incentives.

\begin{tabular}{|c|c|c|c|c|}
\hline \multicolumn{5}{|c|}{ Corporate culture development model using a motivation system } \\
\hline \multicolumn{2}{|l|}{$\checkmark$} & \multicolumn{3}{|c|}{$r$} \\
\hline \multicolumn{2}{|l|}{$\begin{array}{l}\text { Goal: to increase the level of } \\
\text { corporate culture through the } \\
\text { development of teamwork. }\end{array}$} & \multicolumn{3}{|c|}{$\begin{array}{l}\text { Methodological approaches: activity-based, } \\
\text { situational, personal } \\
\text { Principles: development, unity of theory and } \\
\text { experiment, universal connection }\end{array}$} \\
\hline \multicolumn{5}{|c|}{ Areas of work } \\
\hline & & $\downarrow$ & & $\downarrow$ \\
\hline $\begin{array}{c}\text { Direction of information } \\
\text { education about corporate } \\
\text { culture }\end{array}$ & $\Longrightarrow$ & ings & $\Longrightarrow$ & $\begin{array}{l}\text { Consolidation of the acquired } \\
\text { knowledge and skills in the process } \\
\text { of performing official duties }\end{array}$ \\
\hline
\end{tabular}

\begin{tabular}{|c|c|}
\hline \multicolumn{2}{|c|}{ Organization of team activities } \\
\hline $\begin{array}{c}\text { Methods: diagnostics of work motivation } \\
\text { and collective mood, training sessions, } \\
\text { assignment of team tasks, meetings and } \\
\text { informal meetings, creation of corporate } \\
\text { values and staff missions. }\end{array}$ & $\begin{array}{c}\text { Forms: techniques, means of developing team } \\
\text { spirit through role-playing games, business } \\
\text { games, group exercises, business cases, } \\
\text { imitation of office situations, corporate events, } \\
\text { contests and quizzes, an intellectual club. }\end{array}$ \\
\hline
\end{tabular}

\begin{tabular}{|l|l|}
\hline \multicolumn{2}{|c|}{ Result: an evolving corporate culture and increased productivity } \\
\hline Success criteria: & Success rates: \\
Formed teamwork mechanism; & - reproductive \\
Stable level of motivation; & - informational \\
Prevailing involvement in activities; & - communicative \\
Moderate / high interest in overall results. & - personal \\
\hline
\end{tabular}

Figure 1. Corporate culture development model.

A more extended system of personnel motivation considered in the works of Z.M. Sadvakasova includes two motivation types: moral stimulation (involvement in management, in the composition of an expert group, granting the right to participate in commissions) and personal growth (referral to refresher courses, seminars, workshops not only in the country, but also abroad; provision of sabbatical inspiration comes; provision of methodological day); several methods of stimulating the quality of work: public recognition of the individual; public recognition of a group of people; personal recognition of merit, as well as types of motivation for intangible rewards: general corporate events; expressions of appreciation; workplacerelated rewards; maintaining internal communications; career development and staff rotation; self-development of personality; delegation of powers (Sadvakasova, 2010, 193).

Scientists from different countries have proven the effectiveness of using the system for assessing Key Performance Indicators (KPI). According to the data presented, the authors once again proved the effectiveness of using this system, which helped us to quantify the company's results after the research.

To determine how the development of corporate culture based on increased motivation affected the results of bank productivity, the KPI system was used. KPI is a system for determining key performance indicators of organizations, which allows you to measure the degree of achievement of goals or the effectiveness of the process - effectiveness and efficiency. 
The common KPI result is presented by the results of the assessment of certain tasks of the call centre for the quarter (July, August, September) and includes the average percentage of effectiveness (Table 1).

Table 1

KPI Results of Call centre

\begin{tabular}{|l|c|c|c|c|c|c|c|}
\hline \multicolumn{1}{|c|}{ Months } & SL & FCR & $\begin{array}{c}\text { Percentage } \\
\text { of lost } \\
\text { calls }\end{array}$ & $\begin{array}{c}\text { Percentage of } \\
\text { lost calls at the } \\
\text { operator level }\end{array}$ & $\begin{array}{c}\text { Observation } \\
\text { checklist } \\
\text { CLN } \geq \mathbf{8 0} \%\end{array}$ & $\begin{array}{c}\text { Knowledge } \\
\text { Testing } \geq \mathbf{8 0} \\
\%\end{array}$ & $\begin{array}{c}\text { Customer } \\
\text { self-service } \\
\text { rate } \geq \mathbf{2 8} \%\end{array}$ \\
\hline July & $79 \%$ & $88 \%$ & $12 \%$ & $0.68 \%$ & $84 \%$ & $79 \%$ & $14 \%$ \\
\hline August & $89 \%$ & $82 \%$ & $7 \%$ & $0.37 \%$ & $82 \%$ & $80 \%$ & $11 \%$ \\
\hline September & $90 \%$ & $82 \%$ & $5 \%$ & $0.82 \%$ & $81 \%$ & $88 \%$ & $12 \%$ \\
\hline $\begin{array}{l}\text { Average for } \\
\text { the quarter }\end{array}$ & $86 \%$ & $84 \%$ & $8 \%$ & $0.62 \%$ & $82 \%$ & $82 \%$ & $12 \%$ \\
\hline
\end{tabular}

According to the KPI results, the call centre employees managed to maintain performance indicators and achieved success in the following areas of activity:

- $\mathrm{SL}$ - Service Level - service level which is an indicator of the activity of the call centre for processing calls;

- FCR - First Call Resolution - an indicator that determines the percentage of calls when the operator resolves the customer's question from the first call without ringing back;

- CLN - Observation checklist - assessment of the quality of work with clients, which includes an assessment of the duration of the call, the proactivity of the operator, the correctness of the provision of advice and cross-selling.

- knowledge testing is an indicator of the level of successful passing of weekly tests for knowledge of the Bank's product line, where $100 \%$ success is $80 \%$;

- the level of customer self-service - an indicator of how much operators teach on the line of Customers to use self-service functions independently (they offer the use of Internet banking, self-checking the balance on a payment card through IVR (Interactive Voice Response) or other services.

Based on the personal assessment of each employee individually, the authors were able to calculate the performance results for cross-selling tasks (Table 2).

Table 2

Cross-selling report for the quarter

\begin{tabular}{|l|c|c|}
\hline \multicolumn{1}{|c|}{ Month } & $\begin{array}{c}\text { Number of payment cards } \\
\text { sold }\end{array}$ & $\begin{array}{c}\text { Number of opened loan } \\
\text { applications }\end{array}$ \\
\hline July & 84 pieces & 1112 pieces \\
\hline August & 374 pieces & 962 pieces \\
\hline September & 635 pieces & 1200 pieces \\
\hline Totals for the quarter & 1093 pieces & 3274 pieces \\
\hline
\end{tabular}

As a determination of the leading motive among employees as a criterion of success, the authors developed and used a model for the development of corporate culture using a motivation system, a test method was carried out, which determined the following results. Based on the employee motivation test, it is possible to identify which of the five motivational types is characteristic of the sample of bank employees: reward motive, social motive, process motive, achievement motive and ideational motive. The test consists of ten questions with five choices of answers. The researcher is asked to rank the answer options by assigning number five to the answer that is most correct for the respondent, number four to a less appropriate answer and so on up to number one. (Figure 2).

For $17 \%$ of the interviewed respondents, the leading motive is the reward motive - when an employee works for money, profit and material benefits in the form of bonuses and allowances. As noted by $29 \%$ of the respondents - motivated by social attitudes - for this part of the respondents, it is important to be approved by the management, reinforced with praise and respect from the team. This indicator tells us that the attention from the management has a positive effect on the employee's motivation and increases the importance of the tasks performed by the employee in the eyes of the employee. Pleasure from the work 
process, enjoyment of one's own results are the leading motive for $22.4 \%$ of the respondents. This motive for employees is an internal navigator for fulfilling the plan of tasks, which also compensates for the material side of motivation when an employee works not for profit, but for his own development. According to the research, $18.2 \%$ of the respondents preferred the achievement motive - when the employee is striving towards the goal of self-assertion and self-realization, finding his own path, and paving the way to achieving high goals. To work and invest in achieving the company's common goals, together with the company's ideas to implement projects, became the leading motive for $21.4 \%$ of the surveyed employees.



Figure 2. Determination of the "leading" motive among employees (\%).

During the monitoring and implementation of the Global Motivation Fund, the authors agree with the A.A. Zhaitapova and Z.M. Sadvakasova (2019) proposals which should be followed while managing personnel:

- nonmonetary motivation of staff;

- nonmonetary incentive ideas for staff;

- inexpensive activities;

- corporate motivation.

Nonmonetary motivation of staff: help employees to see the results of their work and use their capabilities; offer interesting tasks during breaks and engage employees in their free time with useful activities; use as motivators titles such as "Best of ... month", "Best Department Specialist"; organise timely provision of complete and reliable information; organise providing autonomy (opportunity to choose ways of decision); allow participation in decision making;

What ideas it is advisable to adhere to the management of nonmaterial incentives for personnel: Praise employees for their work aimed at achieving the main objectives of the company; take an interest in the opinions of employees, involve them in developing ideas and making decisions; allow employees to independently manage their development; demonstrate trust in employees' honesty and sense of responsibility; demonstrate to employees that you are interested in their development; focus more closely on the individual approach to employees; Practice personnel changes; The most pronounced needs of experienced professionals are the need for reward, recognition and status. In this case, the stimulating factors will be appropriate material reward, honorary awards, personnel changes and a prestigious position. For less experienced professionals, the need for safety and accessories will come to the fore. Therefore, the best motivators for them will be a social package and participation in corporate events that provide for informal interaction and contribute to team building; maintain a positive emotional attitude; use entertainment as an incentive. 
Low-cost arrangements: arrange for a parking space in front of the front entrance for a month; arrange for free cinema tickets (theatre, swimming pool); allow a prestigious car to be used to visit a major client; consider offering free handyman services when repairing an employee's flat, provided that the employee pays for the materials themselves; discuss providing one paid holiday for the employee at a time convenient to them without regard to the holiday schedule.

Corporate motivation: carry out corporate adaptation of new employees to inspire them to work; consider targeted use of corporate press (outlining corporate values and rules in brochures and messages); organise displaying texts that list corporate slogans, values and rules on the organisation's stands; introduce regular speeches by the management with the wording of corporate values, goals and rules; start 'pumping up' the staff every morning before work by singing anthems, leading employees' speeches with the wording of work goals; offer regular repeating of the values, goals and principles of the corporate culture for the employees to deeply assimilate them; to conduct business trainings with boarding house visits, conducted with a certain regularity (for example, one training per quarter) and aimed at increasing the professionalism of employees and developing their "common language" and common approaches to work; to offer teambuilding trainings aimed at creating common communication and emotional experience of participants, as well as reducing internal competition, reducing the level of conflict and optimising the social and psychological atmosphere in the organisation; having to arrange anti-stress trainings.

As a result, the development of corporate culture, including the use of the motivation system, is realized with the help of a systematically built model, and is not limited to the applied methods of organizing labour activity. Each block of the model requires clarity of execution and regular inclusion of elements of corporate culture in the workflow - planning meetings, organization of the workplace, collective meetings, minute praise and others.

\section{Conclusions}

Thus, the hypotheses that the authors put forward have been confirmed and rejected in our study.

Hypothesis №1, which assumes the development of the level of corporate culture based on the motivational system with the consequent increase in the productivity of the organization is confirmed, an increase in the fulfilment of the sales plan is visible.

Hypothesis №2, which states that the motivational system for employees is effective not only when using material (monetary) incentives was also confirmed, and it is visible that one of the winning factors of performance were the elements of the motivational system for increasing level of corporate culture.

Hypothesis №3, that the main motivating incentive for contact centre employees is financial rewards, was disproved and based on the final test to determine the leading performance motive, was confirmed: the reward motive scored the lowest and was last on the list.

The results of the study showed that in the studied organization the work process is weakly supported by the system of labour motivation and the level of corporate culture is at a low level. The results of the analysis served as an information basis for the development and substantiation of methods for improving corporate culture, whereas the motivational system.

For competent leadership of the team and corporate culture when forming a personnel motivation system, the authors recommend following the following steps:

1. diagnostics of the existing system of motivation;

2. formulation of goals and policies of the organization in the field of motivation;

3. development of a system of material and nonmaterial incentives;

4. development of internal regulatory documents that fix the system of motivation and incentives for personnel.

Thus, a study was carried out to study the motivation of employees in the context of the innovative development of corporate culture: an analysis of their mutual influence at the theoretical and practical level was carried out; based on the results of the constructed diagnostic study, a model for the development of corporate culture was developed using the personnel motivation system. 


\section{Bibliography}

1. Argyris C., Schön D.A. (1995). Organizational Learning II: Theory, Method, and Practice. Reading: Addison-Wesley.

2. Arh T., Jerman Blaézic B., Dimovski V. (2012). The Impact of Technology-Enhanced Organisational Learning on Business Performance: An Empirical Study. Journal for East European Management Studies, 17(3), 369-383. Retrieved from http://hdl.handle.net/10419/84022

3. Barth A. (2015). The Role of Corporate Culture in the Financial Industry. In Beiträge zur Jahrestagung des Vereins für Socialpolitik Ökonomische Entwicklung - Theorie und Politik. Retrieved from http://hdl.handle.net/10419/112922

4. Bennett B., Gopalan R., Thakor A.V. (2016). The Structure of Bankers' Pay. Working Paper No. 2016-12. Columbus, OH: Fisher College of Business, Charles A. Dice Center. doi: $10.2139 / \mathrm{ssrn} .2795260$

5. Carretta A., Vincenzo F., Fiordelisi F., Schwitzer S. (2006). Corporate Culture and Shareholder Value in the Banking Industry. MPRA Paper 8304, University Library of Munich, Germany. Retrieved from https://mpra.ub.uni-muenchen.de/8304/

6. Cheung Y.L., Tan W., Wang W. (2020). Where do banks value corporate social responsibility more? Evidence on the role of national culture. Journal of Banking and Finances, 118, No 105810. doi: 10.1016/j.jbankfin.2020.105810

7. Dabija A.E. (2019). The Role of Organizational Culture in Improving the Performance of Banking Organizations. Vision 2025: Education Excellence and Management of Innovations through Sustainable Economic Competitive Advantage, 6424-6432.

8. Davidova J., Kokina I. (2018). Paradigms, Approaches and Principals of Knowledge Management. In V. Dislere (Ed.), The Proceedings of the International Scientific Conference Rural Environment. Education. Personality (REEP), 11. Jelgava: Latvia University of Life Sciences and Technologies, 58-65. doi: 10.22616/REEP.2018.006

9. Dyer W.G., Dyer W.G.J., Dyer J.H. (2007). Team Building: Proven Strategies for Improving Team Performance. $\left(4^{\text {th }}\right.$ ed). Wiley, John \& Sons.

10. Golovey L.A., Rybalko E.F. (2002). Praktikum po vozrastnoi psikhologii [Practicum on Age Psychology]. St. Petersburg: Rech. (in Russian)

11. Heller M., Rowlinson M. (2020). Imaged Corporate Communities: Historical Sources and discourses. British Journal of Management, 31(4), 752-768. doi: 10.1111/1467-8551.12349

12. Hellevig J. (2012). Personnel involvement in Russia. Helsinki: Russia Advisory Group Oy. Retrieved from https://www.awaragroup.com/upload/pdf/Employee_Engagement_in_Russia_09_20 12_Preview.pdf

13. Ivanova M., Ignatjeva S. (2018). Harmonization of Organizational Culture Values and Personal Values in Public Sector. In V. Dislere (Ed.), The Proceedings of the International Scientific Conference Rural Environment. Education. Personality (REEP), 11. Jelgava: Latvia University of Life Sciences and Technologies, 364-372. doi: 10.22616/REEP.2018.044

14. Kibanov A.Ya., Batkaeva I.A., Mitrofanova E.A., Lovcheva M.V. (2015). Motivatsiya i stimulirovaniye trudovoy deyatel'nosti. Uchebno-prakticheskoye posobiye [Motivation and stimulation of labor activity. Educational and practical guide]. Moskva: Infra-M. (in Russian)

15. Kuzmynchuk N., Kutsenko T., Terovanesova O., Zhezherun Yu. (2020). Motivation of the Banking Sector Employees in the Context of their Value Orientations. Financial and Credit Activity-Problems of Theory and Practice, 3(34), 63-69.

16. Mooij J. (2004). Corporate Culture of Central Banks: Lessons from The Past. DNB Working Papers 006/2004, Netherlands Central Bank, Research Department. Retrieved from https://www.dnb.nl/binaries/Working\%20Paper\%206_tcm46-146663.pdf

17. Nasri W., Charfeddine L. (2012). Motivating Salespeople to Contribute to Marketing Intelligence Activities: An Expectancy Theory Approach. International Journal of Marketing Studies, 4(1), 168-175. doi: 10.5539/IJMS.V4N1P168

18. O'Donnell O., Boyle R. (2008). Understanding and Managing Organizational Culture. Dublin: Institute of Public Administration. Retrieved from https://www.ipa.ie/_fileUpload/Documents/CPMR_DP_40_Understanding_Managing_Org_Culture.pdf 
19. Padmavathi P., Subrahmanyam D. (2018). A Study on "Organizational Culture in Banking Sector". International Journal of Advanced Educational Research, 3(2), 524-527. Retrieved from http://www.educationjournal.org/archives/2018/vol3/issue2/3-3-33

20. Ryan R.M., Connell J.P. (1989). Perceived locus of causality and internalization: Examining reasons for acting in two domains. Journal of Personality and Social Psychology, 57(5), 749-761. doi: 10.1037/0022-3514.57.5.749

21. Sadvakasova Z.M. (2010). Mirovyye kontseptsii menedzhmenta dlya organizatsii obrazovaniya. Uchebnoye posobiye [World management concepts for the organization of education. Tutorial]. Almaty. (in Russian)

22. Schein E.H. (2013). Organizational Culture and Leadership. ( $4^{\text {th }}$ ed.). Hoboken: The Jossey-Bass.

23. Schein E.H., Schein P.A. (2016). Organizational Culture and Leadership. (5th ed.). Hoboken: John Wiley \& Sons.

24. Senge P.M. (2006). The Fifth Discipline: The Art \& Practice of The Learning Organization. New York: Doubleday Currency.

25. Sergienko O.A., Morozova N.L., Karpets O.S., Babenko M.V. (2018). Model Aspects of Evaluating Efficiency of the Personnel Management and Motivation. Financial and Credit Activity-problems of Theory and Practice, 4(27), 307-317. doi: 10.18371/fcaptp.v4i27.154121

26. Thakor A. (2016). Corporate Culture in Banking. Economic Policy Review, August, 5-16. Retrieved from https://ssrn.com/abstract=2828071

27. Tikhomirova V.T. (2014). Tekhnologiya opisatel'noy pokhvaly kak instrument upravleniya razvitiyem universal'nykh uchebnykh deystviy mladshikh shkol'nikov [Descriptive praise technology as a tool for managing the development of universal educational actions of primary schoolchildren]. Nachal"naja shkola: problemy i perspektivy, cennosti i innovacii, 7, 162-167.

28. Tokareva A.A., Baronene S.G. (2019). Metodika issledovanija vovlecennosti sotrudnikov universiteta [University Employee Engagement Study Methodology]. University Management: Practice and Analysis, 23(1-2), 11-32. doi: 10.15826/umpa.2019.01-2.001 (in Russian)

29. Wheelwright S.C., Clark K.B. (1992). Revolutionizing Product Development: Quantum Leaps in Speed, Efficiency and Quality. New York: Free Press.

30. Zhaitapova A.A., Sadvakasova Z.M. (2019). TQM v upravlenii organizatsiyey obrazovaniya. [TQM in the management of an educational organization]. Almaty: Kazak Universities. (in Russian) 